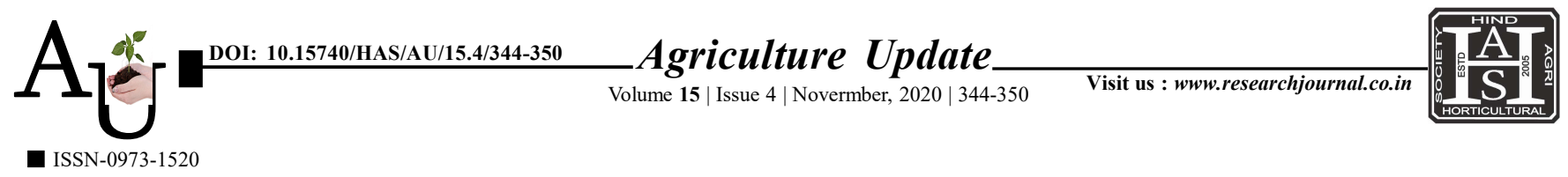

\title{
Research Article: Morphological and cultural variability in Fusarium oxysporum f. sp. cubense causing vascular wilt of banana in Kerala
}

Article Chronicle:

Received :

23.08.2020;

Revised:

01.10.2020;

Accepted :

20.10.2020

KeY WoRds :

Morphological, Cultural variability,

Fusarium oxysporum

f. sp. cubense

causing, Vascular

wilt, Banana
SUMMARY : Fusarium wilt disease caused by Fusarium oxysporum $\mathrm{f}$. sp. cubense (Foc) is one of the most important diseases that affects the banana production which leads to huge economic loss. Thus, to avoid yield loss and manage the disease on time, morphological and cultural characterization of the pathogen is essential as a preliminary identification step. Thirty isolates were collected from different banana growing regions of Kerala. The isolates were grown on half strength PDA medium. The isolates showed extreme variations in their cultural and morphological characters. Most of the isolates produced white coloured aerial mycelium and few of them were greyish white with white to pink pigmentation. Colony diameter ranged from 59.6 to $90.0 \mathrm{~mm}$ at seven days after incubation at $25^{\circ} \mathrm{C}$. The mycelial growth rate varied from $0.83 \mathrm{~cm} /$ day to $2.40 \mathrm{~cm} /$ day. Length and breadth of macroconidia ranged from 15.01 to $20.20 \mu \mathrm{m}$ and 2.14 to $5.07 \mu \mathrm{m}$ whereas, it ranged from 4.49 to $7.42 \mu \mathrm{m}$ and 1.35 to $3.13 \mu \mathrm{m}$ for microconidia. The diameter of chlamydospores varied from 5.68 to $9.58 \mu \mathrm{m}$. Whereas, the inter septal length and breadth of hyphae varied from $16.14 \mu \mathrm{m}$ to $22.94 \mu \mathrm{m}$ and $4.22 \mu \mathrm{m}$ to $6.57 \mu \mathrm{m}$. The cluster analysis based on the quantitative parameters classified the isolates based on variety and genome of the host plants. All the isolates from Rasthali/Poovan (AAB) and Njalipoovan (AB) belonged to the cluster A1 whereas the isolates from Kadali and Chenkadali varieties of banana formed the cluster A2. While, the clustering based on qualitative parameters was irrespective of the variety or genome of the host plant.

How to cite this article : Lishma, N.P. and Anita Cherian, K. (2020). Morphological and cultural variability in Fusarium oxysporum f. sp. cubense causing vascular wilt of banana in Kerala. Agric. Update, 15(4): 344-350; DOI : 10.15740/HAS/AU/15.4/344-350. Copyright@ 2020: Hind Agri-Horticultural Society.
Author for correspondence :

\section{N.P. Lishma}

College of Horticulture, Kerala Agricultural University, Vellanikkara (Kerala) India

Email: lishmanp91@ gmail.com

See end of the article for authors' affiliations 